\title{
Tradisi Nika Leka Pasa Masyarakat Kurang Mampu Di Desa Tangga Kecamatan Monta Kabupaten Bima
}

\author{
Tati Haryati ${ }^{1}$, A. Gafar Hidayat ${ }^{2}$ \\ ${ }^{1,2}$ STKIP Taman SiswaBima \\ 'tatiharyati031@gmail.com
}

\begin{abstract}
ABSTRAK
Penelitian ini betujuan untuk mengetahui proses pelaksanaan tradisi nika leka di Desa Tangga Kecamatan Monta Kabupaten Bima. Penelitian ini merupakan penelitian kualitatif deskriptif dengan menggunakan pendekatan sosial budaya, pendekatan ini digunakan untuk mengungkapkan fenomena yang berkaitan dengan tradisi Nikah Leka sebagai salah satu tradisi kultural dalam adat perkawinan masyarakat Bima. Teknik pengumpulan data meliputi: wawancara, studi kepustakaan dan observasi. Hasil penelitian ini menyimpulkan bahwa tradisi nika leka adalah tradisi pernikahan yang dilaksanakan oleh masyarakat yang tidak memiliki kesanggupan untuk membiayai upacara perkawinan yang mewah dikarenakan alasan ekonomi. Proses pelaksanaanya antara lain: a) Pada proses lamaran nika leka, dilkasanakan hanya oleh kalangan keluarga dekat yang terdiri dari kedua orang tua dengan disaksikan oleh ketua RT dilingkungan tempat tinggal mereka; b) jumlah mahar diserahkan sepenuhnya kepada pihak keluarga calon mempelai laki, jadi pihak mempelai perempuan tidak memaksakan mahar yang tinggi pada keluarga laki-laki; c) Mbolo Weki, adalah salah satu acara yang tidak boleh dilewatkan begitu saja oleh keluarga pasangan nika leka. Acara ini merupakan acara pemberian sumbangan oleh keluarga dan warga masyarakat setempat untuk telesenggaranya sebuah acara pernikahan. Jumlah dana mbolo weki yang terkumpul biasanya tidak terlalu banyak, dana tersebut dipergunakan untuk menambah biaya pernikahan;d) Ritual pernikahan ini di awali dengan acara dende, acara dende ini dilakukan di malam hari yaitu dimana pengantin laki-laki di arak menuju rumah mempelai wanita dengan berjalan kaki diringi dengan musik rebana dan juga zikir. Pengantin laki-laki mengenakan baju adat Bima demikian pula pengantin wanitanya. Acara nika leka dilakukan setelah pelaksanaan sholat Isya dan waktu berakhirnya acara tersebut tidak ditentukan kapan berakhirnya. Karena lama atau sebentarnya acara tersebut itu tergantung sungguh pada tamu yang datang memberikan ucapan selamat. Apabila tamunya sudah tidak ada maka acara nika lekapun berakhir dengan sendirinya.
\end{abstract}

Kata Kunci: Tradisi Nika Leka, Masyarkat Kurang Mampu

\section{PENDAHULUAN}

Manusia pada keseluruhannya mempunyai kesamaan naluri untuk hidup bersama dengan manusia lain. Hidup bersama dan berkerabat merupakan naluri dan kodrat manusia sebagai homopluralis. Manusia sebagai pribadi, mendorong dirinya untuk berjuang dan berkeinginan mempertahankan hidupnya. Sedangkan sifatnya sebagai unsur sosial manusia terdorong oleh keinginan hidup bersama dengan orang lain. Oleh karena itulah manusia diciptakan oleh Tuhan dalam berjenis-jenis untuk saling mengadakan hubungan antar sesama manusia dengan manusia lainnya. Manusia tanpa adanya orang lain tidak dapat hidup serta tidak mampu mempertahankan hidupnya. Laki-laki dan perempuan diciptakan untuk saling membantu dan saling membutuhkan karena adanya dorongan seksual yang merupakan kebutuhan psikologis untuk mengembangkan keturunan.

Pernikahan atau Nika ro Neku dalam tradisi Bima memiliki aturan baku. Aturan itu cukup ketat sehingga satu kesalahan bisa membuat rencana pernikahan (nika) menjadi tertunda bahkan batal. Dulu, seorang calon mempelai laki-laki tidak diperkenankan berpapasan dengan calon mertua. Dia harus menghindari jalan berpapasan. Jika kebetulan berpapasan, maka calon dianggap tidak sopan. Untuk itu, harus dihukum dengan menolaknya menjadi menantu. Aturan yang ketat itu tentu menjadi bermakna 
karena ditaati oleh segenap anggota masyarakat. Kini, tentu saja aturan tersebut sudah ditinggalkan. Misalnya "ngge'e" nuru atau tinggal bersama calon mertua untuk mengabdi di sana. Pengertian nika ro neku adalah serangkaian upacara adat yang dilakukan sebelum dan sesudah upacara akad ( lafa). Bagi semua orang tua, akan merasa berbahagia bila bisa melaksanakan sunah Rasul yang menganjurkan muslim dewasa untuk menikah. Oleh sebab itu tidaklah mengherankan bila pelaksanaan pernikahan diawali serta diakhiri dengan berbagai upacara adat sebagai luapan rasa bahagia dan syukur kehadapan Yang Maha Kuasa yaitu Allah SWT. Bagi masyarakat Bima, upacara nika ro neku, merupakan upacara daur hidup yang sangat menentukan masa depan putra-putri mereka. Keluarga, sanak saudara, karib kerabat, dan warga terlibat dalam upacara ini. Karena itu upacara nika ro neku termasuk " Rawi Rasa" (upacara yang harus melibatkan seluruh warga kampung).

Setiap daerah memiliki adat istiadat yang berbeda-beda dalam melaksanakan upacara perkawinan. Perkawinan mengandung banyak manfaat bagi setiap individu dan masyarakat, karena perkawinan merupakan kebutuhan individu dan masyarakat. Keluarga merupakan pabrik utama dalam membangun masyarakat, jika bangunan ini ditegakkan diatas fondasi yang kuat, akan lahir perkawinan yang sukses (Khair, 2006:8)

Pada tradisi masyarakat Bima, upacara perkawinan memegang peranan penting yang sangat menentukan. Perkawinan yang dilakukan oleh masyarakat Bima memiliki perbedaan dengan perkawinan yang dilakukan oleh daerahdaerah lain. Dalam tradisi masyarakat Bima, perkawinan selalu di awali dengan tahapan palinga (mencari tau) Yang merupakan proses awal dari keseluruhan rangkaian tata cara adat di mana seorang jejaka melakukan penjajakan untuk mencari seorang gadis yang akan dijadikan pasangan hidup. Bila dalam tahapan Palinga ini ternyata si jejaka menyukai gadis tersebut dan ingin memperistrinya maka dia akan memberitahukan hal ini kepada orang tuanya. Untuk mewujudkan keinginan sang anak, maka pihak keluarga pria mengirimkan utusan keluaga yang di beri tugas mencari tahu apakah gadis yang di inginkan anak lelakinya tersebut sudah ada yang punya atau belum. Bila belum ada yang punya dan si gadis bersedia menerima maksud hati sang jejaka yang disampaikan oleh utusan nya maka akan dilakukan kesepakatan untuk menentukan saat yang tepat keluarga pihak pria akan datang ke rumah gadis itu untuk melakukan peminangan resmi pada hari yang disepakati, keluarga pihak pria beserta rombongannya akan mendatangi rumah sang gadis untuk meminang, kedua belah pihak keluarga akan mengadakan pembicaraan lebih lanjut untuk dapat berbesan bila ternyata dalam pertemuan sebelumnya tidak ditemukan kata sepakat, kemudian kedua belah pihak menentukan hari, tanggal dan berbagai syarat keperluan adat yang harus di penuhi oleh pihak keluarga pria menjelang pernikahan (Suntea, 2011).

Upacara melamar atau meminang dalam adat Bima di sebut "Panati" sedangkan orang yang di utus untuk melakukan peminangan di sebut "Ompu panati". Bila pinangan di terima, resmilah gadis dan jejaka tersebut berada dalam ikatan pertunangan atau dalam bahasa Bima di sebut "Dou Sodi" (Ompundaru/ Khaerul Muslimin, 2010). Yang unik pada tradisi perkawinan masyarakat Bima yaitu upacara adat yang dilakukan sehari sebelum hari $\mathrm{H}$, tepat nya pada malam hari sebelum akad nikah, di rumah calon pengantin wanita akan dilakukan acara yang di sebut dengan "Upacara Kapanca" atau biasa di sebut dengan malam "Kapanca" yaitu acara penempean daun pacar atau inai untuk calon pengantin wanita, tidak hanya di bagian kuku, tetapi juga di telapak tangan yang jumlah nya harus ganjil (Suntea, 2011).

Berdasarkan observasi awal yang dilakukan oleh peneliti, ternyata urusan derajat atau status sosial dalam adat perkawinan masyarakat Bima memegang peranan yang sangat penting. Derajat serta pekerjaan seorang pemuda sangat menentukan berhasil tidaknya ia meminang seorang gadis yang diidamkannya. Sedangkan kemampuan ekonomi atau kesanggupan untuk membayar maskawin seringkali dikesampingkan 
jika ternyata pemuda yang meminang tersebut tergolong orang yang berstatus sosial yang lebih tinggi.

Perbedaan status sosial juga sangat terlihat pada penyelenggaraan upacara perkawinan di Desa Tangga kecamatan Monta, mulai dari proses persiapan, penyelenggaraan, maupun pada proses akhir upacara perkawinan. Biasanya, upacara pekawinan yang diselenggarakan oleh masyarakat yang berstatus sosial tinggi dituntut harus sempurna dari awal sampai akhir dan dilaksanakan dengan penuh kemeriahan. Sedangkan upacara perkawinan masyarakat yang status sosialnya rendah dilaksanakan secara sederhana dan apa adanya.

Nika leka menjadi salah satu alternatif yang bisa dilaksanakan oleh masyarakat yang berekonomi menengah kebawah di Desa Tangga Kecamatan Monta Kabupaten Bima dalam meresmikan sebuah ikatan pernikahan tanpa harus mengeluarkan biaya yang banyak.

\section{METODE PENELITIAN}

\section{Tahapan Penelitian}

Tahap Persiapan: a) melakukan observasi dan menentukan masalah yang akan dikaji terkait tradisi nika leka di Desa Tangga Kecamatan Monta; b) menentukan informan kunci yang akan memberikan informasi terkait masalah yang diteliti; c) Mendalami literatur untuk menentukan teori yang dianggap tepat dalam mengkaji permasalahan yang diangkat;d) menyusun instrumen pertanyaan untuk mencari serta menggali informasi sesuai rumusan masalah yang ditetapkan.

Tahap Pelaksanaan: a) Melaksanakan penelitian pada objek kajian yang menekankan pencarian informasi pada tokoh masyarakat dan tokoh agama serta pelaku nika leka di Desa Tangga; b) Mengumpulkan informasi ke dalam format pengumpulan data wawancara.

Tahap Akhir: a) Menelaah data sesuai landasan teori melalui uraian secara deskriptif; b) Membuat kesimpulan dan saran berdasarkan temuan penelitian.

\section{Lokasi Penelitian}

Penelitian ini dilaksanakan di Desa Tangga Kecamatan Monta Kabupaten Bima Nusa
Tenggara Barat.

\section{Jenis Penelitian}

Jenis penelitian ini adalah deskriptif kualitatif dengan menggunakan pendekatan sosial dan budaya. Dengan maksud untuk memahami fenomena tentang apa yang dialami oleh subyek penelitian, misalnya perilaku, persepsi, tindakan dan lain-lain dengan cara deskriptif. Selain itu pendekatan ini juga digunakan untuk mengungkapkan fenomena yang berkaitan dengan tradisi Nikah Leka sebagai tradisi kultural dalam adat perkawinan masyarakat Bima.

\section{Metode dan Rancangan Penelitian}

Penelitian ini menggunakan metode kualitatif bersifat deskriptif bertujuan memberikan gambaran yang jelas, objektif, sistematis, dan cermat mengenai fakta-fakta yang diperoleh dari objek yang ditelaah.

\section{Sumber Data}

Sumber data primer diperoleh dari hasil wawancara secara langsung dengan tokoh-tokoh masyarakat dan agama, pasangan suami istri yang melakukan Nika Leka, dan pemuda- pemudi Desa Tangga Kecamatan Monta Kabupaten Bima. Sumber data sekunder diperoleh secara tidak langsung dari informan di lapangan, seperti dokumen dan sebagainya. Dokumen dapat berupa buku-buku, literatur lainnya ataupun gambar-gambar yang berhubungan dengan masalah-masalah penelitian.

\section{Teknik Pengumpulan Data}

Pengumpulan data dalam penelitian ini dilakukan melalui beberapa tahap, yaitu: a) studi lapangan (field Research), diperoleh melalui proses wawancara dengan berbagai pihak yang telah ditentukan sebagai informan atau narasumber, yaitu tokoh masyarakat dan tokoh agama, pasangan yang melaksanakan tradisi nika leka serta pihak-pihak terkait lainnya. b). Studi kepustakaan (library research). Diperoleh melalui penelitian kepustakaan yang bersumber dari buku-buku, dokumen, publikasi dan hasil penelitian terkait tradisi pernikahan adat Bima. c). Observasi, diperoleh melalui hasil pengamatan langsung terhadap obyek yang diteliti. 


\section{HASIL PENELITIAN}

\section{Gambaran Umum Lokasi Penelitian}

Desa Tangga merupakan desa yang berada di wilayah Kecamatan Monta Kabupaten Bima, dengan luas wilayah yaitu $1295 \mathrm{Ha}$, dengan struktur tanah yang datar terletak pada ketinggian 50 mil dari permukaan laut dan luas tanah sekitar 86,735 Ha. Desa ini termasuk desa yang subur dan cocok untuk daerah perkebunan, pertanian dan pertenakan.

Wilayah Desa Tangga dipengaruhi oleh iklim tropis, panas dan hujan yang saling bergantian setiap tahunnya yakni musim hujan yang berlangsung pada bulan November sampai bulan Maret dan musim kemarau berlangsung pada bulan April sampai bulan Oktober dengan temperatur $23-35^{\circ} \mathrm{C}$ dan curah hujan 250 $\mathrm{Mm} /$ tahun yang bervariasi (Data Monografi Desa Tangga Tahun 2016).

Penduduk Desa Tangga terdiri dari suku-suku yang berbeda dan beragam pula Mata 4.313 orang, dan jumlah kepala keluarga sebanyak $1.193 \mathrm{KK}$, maka jumlah laki-laki lebih besar yakni 2.202 jiwa dan perempuan 2.111 jiwa. Mayoritas penduduk beragama Islam berjumlah 4.309 Jiwa dan yang beragama lain atau pemeluk Agama Hindu hanya 4 Jiwa, ke empat pemeluk Agama Hindu tersebut merupakan pendatang yang berasal dari Bali dan berdomisili di Desa Tangga.

\section{Prosedur Pernikahan adat masyarakat Mbojo}

Perkawinan merupakan salah satu sendi kehidupan masyarakat yang tidak dapat lepas dari tradisi yang telah dimodifikasi agar sesuai dengar ajaran yang mereka anut. Seperti adat sudah menyatu bagi masyarakat yang juga ikut berperan aktif dalam mengatur tentang perkawinan. Secara spesifik, praktis adat ini dapat ditemukan dalam perkawinan.

Pernikahan atau nika ra neku dalam tradisi Suku Mbojo di Desa Tangga Kecamatan Monta Kabupaten Bima memiliki aturan baku. Aturan itu cukup ketat sehingga satu kesalahan bisa membuat rencana pernikahan (nika) menjadi tertunda bahkan batal. Dulu, seorang calon mempelai laki-laki tidak diperkenankan berpapasan dengan calon mertua. Dia harus menghindari jalan berpapasan. Jika kebetulan berpapasan maka calon dianggap tidak sopan. Untuk itu harus dihukum dengan menolaknya menjadi menantu. Aturan yang ketat itu tentu menjadi bermakna karena ditaati oleh segenap anggota masyarakat. Kini, tentu saja aturan tersebut mulai ditinggalkan. Misalnya ngge'e nuru atau tinggal bersama calon mertua untuk mengabdi di sana.

Dalam pelaksanaan perkawinan setiap daerah memiliki tata cara atau prosedur tertentu yang membedakan satu dengan yang lainnya. Adapun prosedur yang harus dilakukan dalam pelaksanaan pernikahan tersebut antara lain : dou sodi (pendekatan/ pacaran), panati (meminang), mbolo weki (musyawarah menentukan hari), wa'a co'i (antar mahar), teka ra ne'e (sokongan), , kapanca (penempelan daun pacar secara simbolik pada calon pengantin wanita), lafa (akad nikah), jambuta (resepsi/ pesta), boho oi ndeu (mandi kembang).

\section{Dou Sodi}

Upacara melamar atau meminang dalam bahasa daerah Bima disebut panati. Orang yang diutus untuk melakukan pinangan disebut Ompu Panati. Bila pinangan itu diterima, resmilah kedua remaja berada dalam ikatan pacaran. Satu dengan yang lain disebut dou sodi (dou artinya orang, sodi artinya tanya, maksudnya orang yang sudah ditanya isi hatinya dan sepakat untuk dinikahkan). Karena sudah saling diikat, yang seorang sudah menjadi dou sodi yang lain, kedua remaja itu tak bebas lagi untuk mencari pacar lain (Khaerul, 2001:15).

Jika kedua remaja itu sudah mengikat janji, biasanya perempuan meminta sang pria agar mengirim orang tuanya. Biasanya sodi angi tidak berlangsung lama melainkan langsung diikuti dengan melamar sang gadis. Tujuannya, antara lain, untuk menghindari fitnah dan hal-hal lain yang tidak terpuji.

\section{Panati}

Dalam tradisi Suku Mbojo, panati menjadi pintu gerbang menuju ke jenjang pernikahan. Panati adalah melamar atau meminang perempuan. Panati diawali dengan datangnya utusan pihak laki-laki ke orang tua perempuan. Utusan datang untuk menanyakan apakah sang gadis sudah memiliki kumbang atau calon 
suami. Bila memperoleh jawaban bahwa sang perempuan berstatus bebas, kembali dilakukan pendekatan untuk mengetahui apakah perempuan itu dapat dilamar. Jika lamaran itu diterima oleh pihak perempuan, si pria melakukan apa yang disebut wi'i nggahi. Pada hari yang ditetapkan, pertunangan diresmikan dalam upacara pita nggahi.

Setelah terjadi acara pertunangan, pada zaman dulu ada acara ngge'e nuru. Akan tetapi adat ini sudah jarang dilaksanakan pada zaman sekarang. Ngge'e nuru maksudnya calon suami tinggal bersama di rumah calon mertua. ngge'e artinya tinggal, nuru artinya ikut. Pria sudah diterima lamarannya, bila kedua belah pihak menghendaki, sang pria diperkenankan tinggal bersama calon mertua di rumah calon mertua. Dia akan menanti bulan baik dan hari baik untuk melaksanakan upacara pernikahan.

Berdasarkan hasil wawancara peneliti dengan Isra A.Wahab selaku Kepala Desa Tangga, maka dapat peneliti uraikan bahwa datangnya sang pria untuk tinggal di rumah calon mertua inilah yang disebut dengan ngge'e nuru. Selama terjadinya ngge'e nuru, sang pria harus memperlihatkan sikap, tingkah laku dan tutur kata yang baik kepada calon mertuanya. Bila selama ngge'e nuru ini sang pria memperlihatkan sikap, tingkah laku dan tutur kata yang tidak sopan, malas dan sebagainya, atau tak pernah melakukan shalat, lamaran bisa dibatalkan secara sepihak oleh keluarga perempuan. Ini berarti ikatan sodi angi diantara dua remaja tadi putus. Tujuan utama ngge'e nuru ini adalah proses adaptasi antara sang pria dengan kehidupan calon mertua. Selama ngge'e nuru, pria tidak diperkenankan bergaul bebas dengan perempuan calon istrinya. Akan tetapi tradisi ngge'e nuru ini sudah tidak lagi dilaksanakan/ diberlakukan dalam masyarakat pada zaman sekarang.

\section{Mbolo Weki}

Mbolo weki adalah upacara musyawarah dan mufakat seluruh keluarga maupun handai taulan dalam masyarakat untuk merundingkan segala sesuatu yang berhubungan dengan pelaksanaan hajatan/ rencana perkawinan yang akan dilaksanakan. Dalam tradisi khitanan juga demikian. Hal-hal yang dimufakatkan dalam acara mbolo weki meliputi penentuan hari baik, bulan baik untuk melaksanakan hajatan tersebut serta pembagian tugas kepada keluarga dan handai taulan. Bila ada hajatan pernikahan, masyarakat dengan sendirinya bergotong royong membantu keluarga melaksanakan hajatan. Bantuan berupa uang, hewan ternak, padi/ beras dan lainnya. Adapun jumlah bantuan yang diberikan ada yang bersifat ditetapkan dan ada pula bersifat sukarela. Jumlah bantuan mbolo weki ini akan dicatat dalam buku dan sebagai bahan pertimbangan kembali mana kala orang yang memberi bantuan tersebut mengadakan acara mbolo weki. Dengan demikian acara mbolo weki ini dapat dikatakan bantuan secara bergantian.

\section{Wa'a Co'i}

Wa'a co'i maksudnya adalah upacara menghantar mahar atau mas kawin, dari keluarga pria kepada keluarga sang gadis. Dengan adanya upacara ini, berarti beberapa hari lagi kedua remaja tadi akan segera dinikahkan. Banyaknya barang dan besarnya nilai mahar, tergantung hasil mufakat antara kedua orang tua remaja tersebut. Pada umumnya mahar berupa rumah, perabotan rumah tangga, perlengkapan tidur dan sebagainya. Tapi semuanya itu harus dijelaskan berapa nilai nominalnya.

Upacara mengantar mahar ini biasanya dihadiri dan disaksikan oleh seluruh anggota masyarakat di sekitarnya. Digelar pula arakarakan yang meriah dari rumah orang tua sang pria menuju rumah orang tua perempuan. Dengan diiringi seni/ musik hadrah, sholawatan, maupun kesenian Mbojo lainnya, semua perlengkapan mahar dan kebutuhan lain untuk upacara pernikahan seperti beras, kayu api, hewan ternak, jajan dan sebagainya ikut dibawa dan diarak.

\section{Teka Ra Ne'e}

Teka ra ne'e ke keluarga yang melaksanakan hajatan merupakan kebiasaan di kalangan Suku Mbojo. Teka ra ne'e berupa pemberian bantuan pada keluarga yang mengawinkan putra putrinya. Bila upacara teka ra ne'e dimulai, berduyun-duyunlah masyarakat (umumnya kaum 
wanita) datang ke rumah keluarga berhajat dengan membawa uang, bahan pakaian, beras dan sebagainya.

\section{Kapanca}

Upacara ini dilaksanakan sehari sebelum calon penganti wanita dinikahkan. Setiba di uma ruka, calon pengantin wanita akan melaksanakan acara adat yang disebut kapanca, yaitu acara penempelan kapanca (inai) di atas telapak tangan calon pengantin wanita. Dilakukan secara bergiliran oleh ibu-ibu pemuka adat. Kapanca merupakan peringatan bagi si calon pengantin wanita bahwa dalam waktu yang tak lama lagi akan melakukan tugas sebagai istri atau ibu rumah tangga. Seiring dengan kegiatan kapanca, akan disuguhkan juga sejenis kesenian rakyat yang bernafaskan ajaran Islam yang disebut Zikri Kapanca yang dilakukan oleh grup hadrah yang telah diundang khusus oleh yang berhajat. Mereka akan membawakan syair bernuansa Islam yang liriknya berisi pujian dan sanjungan pada Allah dan Rasul.

Seusai acara Zikir Kapanca dilanjutkan dengan pertunjukan hiburan berupa kesenian dan musik Mbojo Bima seperti malam hadrah, biola/ ketipung semalam suntuk. Ada pula olahraga seperti Guntaw atau tarian seperti Buja Kadanda. Acara hiburan ini biasanya dihadiri oleh kaum laki-laki dan anak-anak muda untuk memeriahkan suasana perkawinan.

\section{Lafa}

Lafa atau akad nikah merupakan puncak acara. Sebelum akad berlangsung, malamnya dilakukan upacara kapanca (memberi atau menghias daun pacar yang digiling halus pada jari-jari tangan dan kaki pengantin). Acara ini disebut londo dende, dimana pengantin pria diantar ramai-ramai oleh keluarga dan handai taulan dengan diiringi kesenian hadrah ke tempat pengantin wanita. Pengantin pria mengenakan pakaian adat pengantin. Kadangkadang kedua pengantin diarak bersama-sama menuju tempat upacara. Seringkali pula hanya pengantin pria yang diarak. Pengantin wanita cukup menunggu di tempat upacara (Muslimin, 2004:9-10).

Di tempat pengantin wanita dipersiapkan berpakaian adat pengantin dan duduk di atas pelaminan yang dihias ornamen-ornamen tradisional. Duduknya di bawah (di atas kasur berhias) dengan bersimpuh menurut adat (doho tuku tatu'u). Ia didampingi seorang inang pengasuh dan dua remaja putri dari keluarga dekat yang bertugas mengipas, selain itu duduk pula dua orang laki-laki atau perempuan yang membawa alat penginang.

Di muka pelaminan duduk berbaris berhadap-hadapan putri-putri remaja yang membawa lilin berhias. Di belakang dan di samping mereka duduk para tamu ibu-ibu dan bapak-bapak. Orang tua pengantin wanita duduk di sebelah pelaminan. Ruangan tersebut dibatasi dengan tirai adat yang disebut dindi ra-lara berwarna-warni. Biasanya dipakai warna merah, hijau, kuning dan putih.

Saat pengantin dan rombongan naik atau masuk ke ruangan, mereka berhenti di depan tirai. Terjadilah semacam dialog pendek antara pengantar (bapak-bapak) pengantin pria dengan penjaga tirai (bapak-bapak) pihak wanita. Setelah diserahkan uang pelumas dan sirih pinang, barulah tirai dibuka oleh ibu-ibu dari pihak wanita dari dalam tirai dan disambung dengan taburan beras kuning, dan menancapkan setangkai kembang ke atas gelung penganting wanita yang duduk membelakangi. Pengantin wanita mencabut kembangnya dan membuangnya (ini dilakukan tiga kali). Acara ini disebut nenggu. Setelah nenggu, pengantin wanita berbalik dan sama-sama duduk berhadapan kemudian pengantin wanita sujud atau salaman dengan pengantin pria. Selanjutnya mereka duduk bersanding untuk disaksikan oleh undangan dan handai taulan.

Berdasarkan hasil wawancara peneliti dengan H. Abdullah selaku tokoh masyarakat, maka dapat peneliti uraikan bahwa pada acara ini seluruh masyarakat, pemuka agama, laki prempuan diundang untuk menyaksikan dan memberi do'a restu. Pelaksanaan upacara ini bermacam-macam. Kadang-kadang hanya dengan selamatan biasa yang disebut do'a jama. Kadangkadang dengan pesta yang cukup meriah dengan diiringi orkes atau band. Dengan disaksikan oleh seluruh tamu, dihadapan petugas agama, saksi khusus, pengantin pria duduk berhadapan 
dengan calon mertuanya, berpegangan tangan dalam posisi dua ibu jari kanan mereka saling dirapatkan. Dalam posisi demikian, diadakanlah akad nikah atau ijab kabul yang dalam bahasa daerah disebut lafa. Akad nikah atau ijab kabul atau lafa harus didahului dengan mengucapkan kalimat syahadat yang diucapkan oleh calon mertua atau wali dengan diikuti oleh mempelai pria.

Selesai mengucapkan akad nikah, resmilah si pria menjadi suami si wanita. Proses selanjutnya adalah mengantar pengantin laki-laki menuju tempat duduk pengantin wanita dengan diantar oleh penghulu atau siapa saja yang ada di sekitar itu untuk melakukan upacara caka (jengkal) yaitu ibu jari kanan pengantin pria diletakkan di atas ubun-ubun pengantin wanita yang disusul dengan saling berjabat tangan antar kedua pengantin yang selanjutnya mereka duduk bersanding. Caka dimaksudkan sebagai pertanda permulaan sang suami menyentuh istrinya dan mulai saat itu mereka sudah halal untuk bergaul sebagai suami istri.

\section{Jambuta}

Ada sebuah acara yang menjadi bagian dari prosesi perkawinan yaitu jambuta. Semula acara ini hanya berlaku di kalangan etnis Arab, namun akhirnya menjadi bagian dari tradisi Suku Mbojo pada umumnya maupun masyarakat Desa Tangga pada khususnya. Jambuta hampir sama tujuannya dengan teka ra ne'e namun pelaksanaannya cukup satu hari. Sedang teka ra ne'e berkisar antara dua hingga tiga hari (Khaerul, 2001:18).

\section{Boho Oi Ndeu}

Boho oi ndeu adalah mandi sebagai pertanda ucapan selamat tinggal atas masa remaja. Boho oi ndeu ini dilakukan sehari setelah akad nikah, dilangsungkan tapi sebelum pengantin bergaul sebagai suami istri. Pada upacara ini kedua pengantin duduk bersama pada tempat tertentu yang telah disediakan. Kemudian dari atas kepalanya oleh dukun dituangkan air yang sudah disiapkan dalam periuk tanah yang baru (roa bou; roa artinya periuk; bou berarti baru). Leher periuk dilingkari dengan segulung benang putih. Boho oi ndeu biasanya dilakukan pagi hari yang disusul dengan do'a selamatan pada sore harinya. Kedua pengantin duduk berdampingan, menduduki suatu alat tenun yang disebut lira, sedangkan badan mereka dililit dengan untaian benang tenun dari kapas putih sebagai lambang ikatan suci kemudian dilakukan siraman dengan air wangi-wangian. Inilah akhir dari upacara nika ra neku (Muslimin, 2004:13).

Acara mandi untuk calon pengantin wanita dilakukan juga sebelum upacara perkawinan, yakni pada pagi hari sebelum acara kapanca. Mandi ini disebut boho oi mbaru yang artinya memandikan atau menghapus masa kegadisan bagi calon pengantin wanita. Setelah mandi dilanjutkan dengan boru atau cukuran yaitu mencukur dahi calon mempelai wanita menurut bentuk dandanan yang diperlukan.

Pada hari ketiga, pengantin wanita diboyong ke rumah pengantin pria dalam acara yang disebut lao keka. Di tempat pengantin pria, diadakan acara pamaco, dimana kedua pengantin diperkenalkan pada para undangan yang satu per satu menyampaikan sumbangan, entah uang atau barang, bahkan secara simbolis menyerahkan seuntai tali apabila hadiahnya hanya merupakan seekor kerbau.

Berdasarkan hasil penelitian di atas, maka peneliti dapat mengambil kesimpulan bahwa prosedur pelaksanaan perkawinan Suku Mbojo di Desa Tangga Kecamatan Monta Kabupaten Bima meliputi: dou sodi (pendekatan/ pacaran), panati (meminang), mbolo weki (musyawarah menentukan hari), wa'a co'i (antar mahar), teka ra ne'e (sokongan), kapanca (penempelan daun pacar secara simbolik pada calon pengantin wanita), lafa (akad nikah), jambuta (resepsi/ pesta), boho oi ndeu (mandi kembang). Banyaknya acara prosesi perkawinan yang harus dilaksanakan tersebut, secara otomatis memerlukan biaya perkawinan yang cukup besar. Karena itulah, sebagian biaya pelaksanaan perkawinan tersebut dibebankan pada penentuan mahar (wa'a co'i).

Proses pelaksanaan Tradisi Nika Leka di Desa Tangga Kecamatan Monta Kabupaten Bima

Tradisi nika leka adalah tradisi pernikahan yang dilaksanakan oleh masyarakat yang tidak memiliki kesanggupan untuk membiayai upacara perkawinan yang mewah dikarenakan alasan 
ekonomi. Tradisi nika leka ini prosesnya hampir sama dengan pernikahan biasa yang umumnya dilakukan oleh masyarakat Bima. Yang membedakannya hanyalah pada pesta perayaannya saja. Hal ini seperti yang di sampaikan oleh bapak Isra A.Wahab selaku Kepala Desa Tangga: "bahwa nika leka ini sudah ada sejak dahulu, dan biasanya dilaksanakan oleh masyarakat yang rata-rata tidak memiliki kemampuan dalam bidang ekonomi/ masyarakat miskin. Lain halnya dengan upacara perkawinan masyarakat yang tingkat ekonomi dan status sosialnya tinggi. Masyarakat yang berstatus sosial tinggi dalam melaksanakan upacara perkawinan selalu ingin terlihat sempurna, oleh karena itu sebelum pelaksanaan upacara perkawinan mereka membentuk panitia yang khusus bertugas untuk mempersiapkan hajatan besar tersebut, mulai dari konsep upacara pernikahan, undangan, gedung sebagai tempat pelaksanaan upacara pernikahan, busana yang dikenakan mulai dari busana pengantin sampai pada busana yang akan dikenakan oleh pagar ayu (pengiring pengantin), tukang rias, hiburan, konsumsi para tamu, dan lain sebagainya.

Seperti yang diungkapkan oleh Imran salah satu warga Desa Tangga, "bahwa: bagi saya pernikahan adalah sekali seumur hidup, oleh karenanya saya ingin pesta pernikahan saya harus terlihat mewah dan sempurna. Maka dari itu dari proses persiapan sampai pelaksanaannya sebisa mungkin saya kontrol sendiri, agar saya mengetahui langsung kekurangankekurangannya.

Upacara perkawinan yang dilaksanakan oleh masyarakat yang berstatus social tinggi di Desa Tangga umumnya hampir sama dengan pelaksanaan perkawinan yang dilaksanakan oleh masyarakat Bima yaitu diawali dengan pacaran, pertunangan, mengutus panati, pengantaran mahar, sokongan, resepsi, akad nikah dan mandi kembang.

Terkait dengan nika leka di Desa Tangga Kecamatan Monta, pada umumnya prosesi yang dilewati hampir sama dengan pernikahan yang seperti biasanya hanya saja dilakukan secara lebih sederhanan, mulai dari proses lamaran, akad nikah dan resepsi pernikahan.

\section{Proses Lamaran}

Pada proses lamaran nika leka, dilkasanakan hanya oleh kalangan keluarga dekat yang terdiri dari kedua orang tua dengan disaksikan oleh ketua RT dilingkungan tempat tinggal mereka. Pada proses lamaran ini pihak laki-laki menanyakan kesiapan dari pihak perempuan apakah bersedia untuk menikah dan kira-kira berapa jumlah mahar yang harus disiapkan oleh pihak laki-laki. Pada umumnya, apabila ditanyakan tentang jumlah mahar yang akan dibawa, jawaban dari pihak perempuan adalah seberapa saja kemampuannya. Dengan kata lain pihak perempuan menyerahkan sepenuhnya tentang mahar itu sekemampuan pihak laki-laki, jadi pihak perempuan disini tidak memaksakan mahar yang tinggi pada keluarga laki-laki.

Hal ini seperti dijelaskan oleh bapak usman selaku ketua RT 04, beliau mengatakan bahwa keluarga yang melaksanakan nika leka pada saat melakukan acara lamaran biasanya tidak melibatkan orang lain melainkan kedua orang tuannya langsung dan hanya melibatkan ketua RT sebagai saksi lamarannya. Dan pada saat proses lamaran itu juga langsung dibicarakan masalah maharnya, sebagai pihak yang dilamar, pihak perempuan biasanya tidak memaksakan mahar pada laki-laki yang penting bagi mereka pernikahan tersebut jadi dilaksanakan.

Hasil wawancara di atas diperkuat lagi dari hasil wawancara peneliti dengan Sahidah, yaitu pelaku nika leka. Mengatakan bahwa "saya dan suami saya adalah orang tidak berada, pada saat dulu suami saya melamar saya, saya tidak membebaninya dengan masalah mahar karena saya tau sekali bagaimana kondisi ekonominya. Yang penting bagi saya pernikahan itu tetap berlangsung meskipun dengan mahar yang sedikit.

Dari beberapa hal yang disampaikan oleh narasumber di atas maka dapat disimpulkan bahwa proses lamaran pasangan yang melaksanakan nika leka sedikit berbeda dengan proses lamaran yang dilakukan oleh keluarga yang melaksanakan pernikahan yang biasa. Dan terkait dengan urusan pembayaran maharpun tidak sesulit dan semahal dari masyarakat yang melaksanakan pernikahan biasa. 


\section{Mbolo Weki}

Mbolo Weki, adalah salah satu acara yang tidak boleh dilewatkan begitu saja oleh keluarga pasangan nika leka. Acara ini merupakan acara pemberian sumbangan oleh keluarga dan warga masyarakat setempat untuk telesenggaranya sebuah acara pernikahan. Jumlah dana mbolo weki yang terkumpul biasanya tidak terlalu banyak, dana tersebut dipergunakan untuk menambah biaya pernikahan.

Seperti yang disampaikan oleh bapak Samsudin kepada peneliti, "bahwa acara mbolo weki bagi masyarakat yang tidak mampu sangat membantu dalam penyelenggaraan pernikahan, meskipun yang dilakukan adalah nika leka tetapi tetap juga membutuhkan biaya.

Undangan Pelaksanaan mbolo weki bagi masyarakat yang tidak mampu berbeda dengan masyarakat yang mampu. Masyarakat yang tidak mampu biasanya menyampaikan undangan mbolo weki kepada masyarakat lewat pengeras suara (mikrofon) dari masjid atau musholah. Sedangkan undangan mbolo weki masyarakat yang mampu itu dilakukan lewat kartu undangan yang disampaikan langsung dari rumah ke rumah.

\section{Akad Nikah}

Acara Akad Nikah, acara akad nikah yang dilakukan oleh pasangan nika leka dilaksanakan dalam suasana yang penuh kesederhanaan, yaitu dilaksanakan di kantor Urusan Agama. Tamu undangan biasanya tidak terlalu banyak, hanya terdiri dari kedua keluarga, teman-teman kedua pasangan dan tetangga-tetangga terdekat. Si pengantin wanita dirias sealakadarnya saja, sama sekali tidak terlihat kemewahan karena hanya di balut dengan kebaya biasa. Baju yang dikenakanpun bukan baju khusus yang disiapkan oleh inang pengasuh (tukang rias) melainkan baju pengantin wanita itu sendiri.

Seperti yang disampaikan oleh Nurjanah kepada peneliti, bahwa pada saat akad nikah dulunya ia mengenakan baju kebaya sendiri yang saat muda biasa dipakai untuk ke pesta pernikahan karena kalau memakai baju yang disiapkan oleh inang pengasuh (tukang rias) berarti harus keluar biaya lagi, sedangkan untuk menyewanya tidak memiliki uang lebih.
Kemeriahan acara akad nikah pasangan nika leka terlihat pada saat pengantin laki-laki berjalan kaki ke kediaman pengantin wanita yang diiringin oleh musik rebana dan rombongan yang membawa hasil bumi, kayu bakar dan bumbu-bumbu masakan, juga hewan sebelihan seperti ayam dan yang paling besar adalah seekor kambing.

Sangat berbeda dengan akad nikah yang dilkasanakan oleh pasangan yang berasal dari keluarga berada dan memiliki derajat yang tinggi di masyarakat. Suasananya penuh dengan kemeriahan dan juga kemewahan, mulai dari tamu undangan, kostum yang dikenakan oleh pasangan pengantin, dekorasi ruangan tempat akad nikah berlangsung, dan juga hidanganhidangan yang disiapkan pada acara akad nikah tersebut.

\section{Resepsi Pernikahan}

Resepsi pernikahan merupakan puncak dari rangakaian upacara pernikahan yang biasanya dilaksanakan pada sore hari. Resepsi ini merupakan acara pemberian ucapan selamat oleh para undangan kepada pasangan pengantin beserta kedua keluarganya. Resepsi pernikahan di Desa Tangga Kecamatan Monta biasanya hanya dilaksanakan oleh masyarakat yang memiliki status social yang tinggi dan tentu saja memiliki kemampuan dalam membiayai pesta tersebut, mulai dari biaya tenda/gedung, biaya penyewaan kursi, penyewaan piring/terop, penyewaan pelaminan, penyewaan orgen, sampai pada penyewaan Inang Pengasuh (tukang rias).

Sedangkan pasangan yang berasal dari keluarga yang tingkat ekonominya rendah tidak mampu melaksanakan resepsi pernikahan ini dikarenakan masalah biaya. Agar pernikahan tetap berlangsung meskipun dengan suasana yang sederhana maka pasangan ini melakukan nika leka, yaitu pernikahan yang dilakukan pada malam hari.

Ritual pernikahan ini di awali dengan acara dende, acara dende ini dilakukan di malam hari yaitu dimana pengantin laki-laki di arak menuju rumah mempelai wanita dengan berjalan kaki diringi dengan musik rebana dan juga zikir. Pengantin laki-laki mengenakan baju adat Bima demikian pula pengantin wanitanya. 
Sesampainya di rumah pengantin wanita kedua pengantin ini dipertemukan, disana terjadi dialog antara antara pengantin laki-laki dan pengantin wanita.

Dialog tersebut berisi si pengantin laki-laki mempertanyakan ke pada si wanita "apakah si wanita ini sudah siap berjalan bersamanya dalam suka maupun duka"? si wanitapun menjawab Iya. Setelah dialog ini berakhir maka pasangan pengantin tersebut kembali di arak jalan kaki mengelilingi kampung sambil diringi musik rebana dan zikir.

Menurut bapak Abdullah tokoh masyarakat Desa Tangga, bahwa tujuan dari diarak-araknya pengantin ini keliling kampung adalah sebagai ungkapan rasa gembira pasangan pengantin dan keluarga serta secara langsung memberitahukan kepada masyarakat Desa Tangga bahwa malam ini akan berlangsung acara nika leka.

Setelah selesai diarak-arak keliling kampung, pasangan pengantin tersebut kemudian disandingkan pada pelaminan sederhana yang lokasinya bisa di lapangan ataupun halaman rumah pengantin wanita. Pada acara nika leka ini, tidak ada susunan acara yang resmi. Tamutamu yang hadir memberikan ucapan selamatpun tidak mengenakan pakaian resmi. Mereka hanya mengenakan pakaian sehari-hari bahkan juga ada yang mengenakan rimpu (kerudung sarung).

Hal tersebut diperkuat dengan hasil wawancara peneliti dengan ibu nur yang mengatakan bahwa " pada acara nika leka kami tidak perlu menggunakan pakaian pesta yang biasanya kami kenakan pada acara pernikahan yang umumnya biasa dilakukan masyaarakat Bima, kami cukup mengenakan pakaian seharihari. Bahkan orang-orang tua di desa kami ini perginya hanya dengan mengenakan sarung dan juga rimpu (kerudung sarung).

Pada lokasi pestapun tidak disediakan kursi untuk para tamu undangan, mereka yang hadir langsung memberikan ucapan selamat dan setelah selesai memberikan ucapan selamat mereka bisa langsung pulang atau berdiri untuk menonton. Kado yang diberikanpun tidak dibungkus dengan kertas kado demikian juga tamu yang memberikan uang, Uang tersebut tidak dimasukkan didalam amplop melainkan langsung diberikan begitu saja.

Acara nika leka dilakukan setelah pelaksanaan sholat Isya dan waktu berakhirnya acara tersebut tidak ditentukan kapan berakhirnya. Karena lama atau sebentarnya acara tersebut itu tergantung sungguh pada tamu yang datang memberikan ucapan selamat. Apabila tamunya sudah tidak ada maka acara nika lekapun berakhir dengan sendirinya.

Berdasarkan hasil wawancara peneliti dengan Bapak Muslim, S.Pd beliau mengatakan bahwa nika leka ini benar-benar dilakukan oleh masyarakat yang tidak mampu di desa kami, mereka tidak mampu mebiayai pesta pernikahan yang memakan biaya puluhan juta. Menyadari kekurangan inilah maka masyarakat melaksanakan nika leka dengan prinsip yang penting syah menjadi pasangan suami istri dimata Allah dan juga masyarakat.

Berdasarkan hasil penelitian maka dapat disimpulkan bahwa salah satu solusi bagi pasangan yang ingin melaksanakan pernikahan tetapi tidak mampu membiayai pelaksanaan upacara pernikahan di Desa Tangga Kecamatan Monta ialah dengan cara melakukan Nika leka.

\section{DAFTAR PUSTAKA}

Amin, Syahroni. (1971). Mahar dalam Tradisi dan Kebudayaan. Yogyakarta: Liberty.

Ayyub, Hasan. (2004). Figh Keluarga. Jakarta: Pustaka Al-Kautsar.

Efendi, Satria. (2004). Problematika Hukum Keluarga Islam Kontemporer. Jakarta: Kencana.

Ghazali. (1995). Menyikap Hakekat Perkawinan. Bandung: PT. Karisma.

Huaidi, Fahmi. (2002). Majmu Fatawa Tentang Nikah. Jakarta: Pustaka Azzam.

Kartohadiprojo, Soediman. (1984). Pengantar Tata Hukum di Indonesia. Jakarta: PT. Ghalia Indonesia.

Kartodirdjo, Sartono. (1992). Pendekatan Ilmu Sosial Metodologi Sejarah. Jakarta: Gramedia.

Khaerul, Muslim. (2001). Adat Pernikahan Bima. Jakarta: Pustaka Azzam.

Kuntowijoyo. (1995). Pengantar Ilmu Sejarah. Yogyakarta: Bentang Budaya. 
Martiman. (2002). Hukum Perkawinan Indonesia. Jakarta: PT. Abadi.

Murtiningdyah. (2005). Kedudukan Wanita dalam Mahar (Studi Kasus di Kabupaten Pare-Pare). Tersedia pada http://etd.eprints.uny.ac.id/pdf. Diakses pada tanggal 1 Oktober 2011.

Muslimin, Hamzah. (2004). Ensiklopedi Bima. Jakarta: Kencana.

Nurdin, Amiur. (2004). Hukum Islam di Indonesia. Jakarta: Kencana.

Peter, B. (2003). Sejarah dan Teori Sosial. Jakarta: Yayasan Obor Indonesia.Prasada. (2010). Penentuan Mahar dan Pengaruhnya terhadap Kedudukan Wanita dalam Masyarakat di Desa Mura Kabupaten Sumbawa Barat. Tersedia pada http://etd.eprints.ums.ac.id/4853/1/G0000 60086.pdf. Diakses pada tanggal 1 Oktober 2011.

Prodjohamidjojo, Soetojo. (1985). Hukum Orang dan Hukum Keluarga. Bandung: Alumni.

Prodjodikoro, Widjono. (1960). Hukum Perkawinan di Indonesia. Bandung: PT. Sumur.

Rahman, Abdullah. (2006). Fiqh Munkahat. Jakarta: Kencana.

Ramulyo, Idris. (2004). Hukum Perkawinan Islam. Jakarta: PT. Bumi Aksara.

Rasyid, Sulaiman. (2004). Figh Islam. Bandung: Sinar Baru Algensindo.

Soemiyati. (1981). Hukum Perkawinan Islam. Yogyakarta: Liberty.

Subekti. (1987). Pokok-Pokok Hukum Perdata. Jakarta: PT. Intermasa.

Syarifudin, Amir. (2003). Garis-Garis Besar Fiqh. Jakarta: Kencana.

Undang-Undang No. 1 Tahun 1974 Tentang Perkawinan.

Wantjik, Saleh. (1976). Hukum Perkawinan Indonesia. Jakarta: PT. Ghalia Indonesia. 